\title{
SOROTAN SEMULA TATABAHASA DEWAN
}

\author{
Khairul Taufiq ABU BAKAR*1 \\ Nor Hashimah JALALUDDIN² \\ Fazal Mohamed MOHAMED SULTAN ${ }^{3}$ \\ ${ }^{1,2,3}$ Pusat Kajian Bahasa dan Linguistik \\ Universiti Kebangsaan Malaysia \\ 1taufiq_urasmi@yahoo.com.my \\ 2shima@ukm.edu.my \\ 3fazal@ukm.edu.my
}

Manuscript received 4 June 2021

Manuscript accepted 6 September 2021

*Corresponding author

https://doi.org/10.33736/ils.3448.2021

\begin{abstract}
ABSTRAK
Kajian ini membincangkan perihal contoh-contoh penggunaan kata kerja yang boleh juga mendukung makna tersirat yang mengikut acuan teori tatabahasa yang berasaskan konsep Transformasi-Generatif didapati boleh juga melanggar sekatan pilihan. Walau bagaimanapun, contoh-contoh penggunaan kata kerja yang boleh juga mendukung makna tersirat tersebut memerlukan perspektif pragmatik melalui pengaplikasian Teori Relevans bagi membolehkan penginterpretasian makna yang lebih mendalam dan sempurna dapat dilakukan. Kajian ini yang tergolong sebagai kajian kualitatif mengguna pakai kaedah analisis dokumen dengan memfokuskan reka bentuk kajian analisis kandungan. Di samping itu, tinjauan melalui borang soal selidik terhadap 96 orang pelajar tingkatan enam juga turut dilakukan bagi melihat keberkesanan Tatabahasa Dewan dalam menghuraikan aspek golongan kata kerja yang selama ini hanya memfokuskan contoh-contoh penggunaan kata kerja yang mendukung makna tersurat semata-mata. Kajian ini mendapati bahawa pengaplikasian Teori Relevans dalam bidang ilmu pragmatik sememangnya telah terbukti dapat membantu menyelesaikan fenomena pelanggaran sekatan pilihan yang melibatkan contoh-contoh penggunaan kata kerja yang boleh juga mendukung makna tersirat. Dapatan kajian daripada kajian ini diharapkan dapat membantu para penulis Tatabahasa Dewan untuk memperoleh inputinput baharu yang bermanfaat. Seterusnya, tokok tambah yang masih boleh dilakukan
\end{abstract}


oleh para penulis Tatabahasa Dewan diharapkan dapat membantu mengukuhkan lagi kredibiliti dan kewibawaan Tatabahasa Dewan itu sendiri sebagai buku "tatabahasa pegangan".

Kata Kunci: Tatabahasa bahasa Melayu; kata kerja bahasa Melayu; sekatan pilihan; kiasan; semantik; pragmatik

\title{
REVISITING TATABAHASA DEWAN
}

\begin{abstract}
This study discussed the examples of verbal use that supports the implied meaning of grammatical theory based on the Transformative-Generative concept that may also violate selectional restrictions. However, the examples of verb use that also support implied meanings necessitates the application of the pragmatic perspective within the purview of the Relevance Theory to ensure a deeper, thorough and more holistic interpretation of meaning. This study is a qualitative study. It adopted the document analysis method and focused on the content analysis study design. Additionally, a questionnaire was also conducted involving 96 form six students to gauge the effectiveness of the Tatabahasa Dewan in explaining aspects of the verb group that have been focusing only on the examples of verb usage which exclusively supports literal meaning. This study found that the application of the Relevance theory in the pragmatics has assisted in solving the phenomenon of selectional restrictions; particularly the verb usage examples that support implied meanings. The findings of this study are expected to provide the writers of the Tatabahasa Dewan with fresh and useful inputs. Furthermore, future additions to the Tatabahasa Dewan are expected to further strengthen the credibility and authority of Tatabahasa Dewan as a "grammar reference" book.
\end{abstract}

Keywords: Malay grammar; Malay verbs; selectional restrictions; figure of speech; semantics; pragmatics

\section{Pendahuluan}

Hakikatnya, sejak terbitnya Tatabahasa Dewan sebagai buku "tatabahasa pegangan" pada tiga dekad yang lalu, pengkaji mendapati bahawa para pengguna bahasa Melayu khususnya murid-murid sekolah rendah dan juga para pelajar sekolah menengah hanya didedahkan kepada contoh-contoh penggunaan kata kerja yang mematuhi sekatan pilihan semata-mata sedangkan dalam keadaan yang tertentu terdapat juga contohcontoh penggunaan kata kerja yang sudah pun terbukti boleh melanggar sekatan 
pilihan. Walau bagaimanapun, apa yang menariknya tentang contoh-contoh penggunaan kata kerja yang sudah pun terbukti boleh melanggar sekatan pilihan tersebut ialah setiap konstruksi ayat yang terhasil masih boleh dianggap sebagai gramatis dan juga bermakna. Apa yang pasti, sekatan pilihan mengikut acuan teori tatabahasa yang berasaskan konsep Transformasi-Generatif sudah pun dibahaskan sejak tahun 1965 oleh Noam Chomsky sendiri (Omego, Anyanwu, \& Onyegbuchulam, 2012; Singer, 2016), bahkan masih belum menemui titik noktahnya dan masih lagi rancak dibahaskan hinggalah ke hari ini boleh ditakrifkan sebagai perihalan kekangan semantik antara elemen leksikal (Wagner \& Mastropietro, 1996). Kekangan sedemikian menolak sebarang bentuk konstruksi ayat yang menunjukkan ciri anomali dari segi semantik seperti yang boleh dilihat menerusi contoh konstruksi ayat (1), iaitu "\#Burung sedang berkhutbah". Secara logiknya, kata kerja tak transitif "berkhutbah" mestilah memilih subjek yang mempunyai fitur manusia, iaitu "khatib" seperti yang boleh dilihat menerusi contoh konstruksi ayat (2), iaitu "Khatib sedang berkhutbah". Hal ini bermakna subjek yang dipilih oleh kata kerja tak transitif "berkhutbah" yang mempunyai fitur selain daripada fitur manusia sememangnya akan ditolak. Di samping itu, sekatan pilihan juga turut menunjukkan keserasian semantik antara predikat dengan subjek. Keadaan ini ternyata jelas menunjukkan bahawa "berkhutbah" sememangnya tidak serasi dengan subjek seperti "burung" memandangkannya tidak mempunyai fitur manusia.

Walau bagaimanapun, pengkaji mendapati bahawa pemberian makna pada peringkat semantik masih belum boleh dianggap sebagai pemberian makna yang lengkap (Jalaluddin, 1992; Oweleke, 2019) memandangkannya tidak dapat membezakan antara subjek "khatib" yang boleh dilihat menerusi contoh konstruksi ayat (2), iaitu "Khatib sedang berkhutbah" dengan subjek "emak" yang boleh dilihat menerusi contoh konstruksi ayat (3), iaitu "Emak sedang berkhutbah" walaupun "emak" juga sememangnya mempunyai fitur manusia. Keadaan ini ternyata jelas menunjukkan bahawa penggunaan fitur dalam memberi makna gagal menjelaskan penginterpretasian makna pada peringkat yang lebih besar daripada perkataan, malahan sekiranya sesuatu perkataan itu sendiri bersifat taksa, maka semantik gagal menginterpretasikannya (Jalaluddin, 1992). Apa yang pasti, walaupun pemilihan "emak" sebagai subjek oleh kata kerja tak transitif "berkhutbah" dalam contoh konstruksi ayat (3) ternyata jelas telah melanggar sekatan pilihan sama seperti contoh konstruksi ayat (1) tetapi contoh konstruksi ayat (3) tidak perlu ditandai dengan simbol tanda pagar atau hashtag (\#) di hadapannya. Hal ini dikatakan demikian kerana simbol tanda pagar atau hashtag (\#) yang hadir di hadapan sebarang bentuk konstruksi ayat melambangkan bahawa sesebuah konstruksi ayat itu sudah pun menyimpang jauh dari segi semantik dan sama sekali tidak dapat ditafsirkan lagi maknanya (Kroeger, 2005). Ketiadaan simbol tanda pagar di hadapan contoh konstruksi ayat (3) ternyata jelas menunjukkan bahawa fenomena pelanggaran sekatan pilihan tidak selalunya akan menghasilkan konstruksi ayat yang tidak gramatis dan juga tidak bermakna (Omego, Anyanwu, \& Onyegbuchulam, 2012). Sehubungan dengan itu, oleh sebab pemberian makna pada peringkat semantik sudah pun jelas terbukti masih belum boleh dianggap sebagai pemberian makna yang lengkap, maka ilmu semantik sememangnya perlu digandingkan 
dengan ilmu pragmatik. Gandingan ilmu semantik dengan ilmu pragmatik dapat dilihat dengan jelas dan nyata melalui pengaplikasian Teori Relevans. Teori Relevans amat menekankan konteks. Tanpa konteks, makna yang diberi lebih bersifat awang-awangan dan hasilnya boleh mengelirukan. Penginterpretasian makna yang berlandaskan konteks mampu mencakupi penginterpretasian makna pada peringkat kata, frasa, klausa, dan ayat (Jalaluddin, 1992). Dalam erti kata yang lebih mudah, fenomena pelanggaran sekatan pilihan yang melibatkan contoh-contoh penggunaan kata kerja yang salah satunya boleh dilihat menerusi contoh konstruksi ayat (3), iaitu "Emak sedang berkhutbah" hanya dapat ditangani dengan sebaik-baiknya dengan memanfaatkan bidang ilmu pragmatik khususnya melalui pengaplikasian Teori Relevans yang dipelopori oleh Sperber dan Wilson (1995).

\section{Sorotan Kajian Lepas}

Dawi (2010) menyatakan bahawa walaupun sudah begitu banyak kajian penguasaan bahasa yang pernah dilakukan, namun masih tidak ramai pengkaji yang melakukan kajian yang berkaitan dengan aspek penggunaan kata kerja dalam kalangan pelajar sedangkan dalam bahasa Melayu itu sendiri, kata kerja sememangnya sentiasa digunakan secara meluas memandangkannya mempunyai peranan yang amat penting dalam memberikan makna kepada sesebuah konstruksi ayat. Di samping itu, aspek golongan kata kerja juga merupakan salah satu aspek tatabahasa bahasa Melayu yang sememangnya perlu dipelajari dan dikuasai oleh para pelajar dengan sebaik yang mungkin. Tambah Dawi (2010) lagi, aspek golongan kata kerja juga merupakan bahagian yang paling besar dalam struktur sintaksis tatabahasa bahasa Melayu yang meliputi setiap konstituen yang terdapat dalam predikat sesebuah konstruksi ayat. Oleh itu, sudah semestinyalah aspek golongan kata kerja boleh dianggap sebagai aspek yang paling penting dalam konteks penguasaan bahasa Melayu secara keseluruhannya. Walau bagaimanapun, pengkaji mendapati bahawa kajian lepas yang dilakukan oleh Dawi (2010) hanya membincangkan perihal tahap penguasaan bahasa para pelajar terhadap aspek penggunaan kata kerja yang hanya dikaitkan dengan faktor-faktor extralinguistics seperti masalah lupa, gangguan emosi, lalai, kurang latihan, dan sebagainya serta faktor kekacauan dan kekeliruan antara bahasa formal atau tidak formal yang berlaku semasa para pelajar mempelajari bahasa pertama.

Selanjutnya, pengkaji ingin menyentuh pula kajian lepas yang dilakukan oleh Jalaluddin dan Nopiah (2011). Apa yang pasti, walaupun hanya terdapat satu soalan yang berkaitan dengan aspek penggunaan kata kerja yang dikemukakan oleh Jalaluddin dan Nopiah (2011) melalui kajian mereka, namun pengkaji merasakan bahawa dapatan kajian daripada kajian lepas ini tetap perlu diberi perhatian yang serius. Hal ini dikatakan demikian kerana berbeza dengan kajian lepas yang dilakukan oleh Dawi (2010) yang didapati lebih memfokuskan usaha untuk menguji, mengukur, dan menilai tahap kecekapan tatabahasa (atau tahap penguasaan para pelajar dari aspek penggunaan kata kerja yang mendukung makna tersurat semata-mata) tetapi sebaliknya Jalaluddin dan Nopiah (2011) didapati telah memilih untuk memfokuskan usaha untuk menguji, 
mengukur, dan menilai tahap kecekapan pragmatik (atau tahap penguasaan para pelajar dari aspek penggunaan kata kerja yang mendukung makna tersirat pula). Walau bagaimanapun, pengkaji mendapati bahawa faktor-faktor yang menjadi penyebab atau punca kepada kelemahan tahap kecekapan pragmatik para pelajar tingkatan empat yang telah berjaya dicungkil atau dikenal pasti oleh Jalaluddin dan Nopiah (2011) sememangnya terbukti hampir sama dengan faktor-faktor yang menjadi penyebab atau punca kepada kelemahan penguasaan bahasa Melayu dalam kalangan pelajar yang telah berjaya dicungkil atau dikenal pasti oleh kajian-kajian lepas yang sedia ada termasuklah kajian lepas yang dilakukan oleh Dawi (2010) itu sendiri. Walau bagaimanapun, pengkaji berpendapat bahawa terdapat satu lagi faktor yang boleh menjadi penyebab atau punca kepada lemahnya tahap kecekapan pragmatik para pelajar tingkatan empat yang tidak dapat dicungkil atau dikenal pasti oleh Jalaluddin dan Nopiah (2011). Faktor yang dimaksudkan ialah faktor buku rujukan utama yang digunakan oleh para pelajar seperti yang pernah ditekankan oleh Sejo (2012) dan Wong dan Yeo (2018).

Sekiranya Dawi (2010) didapati lebih memfokuskan usaha untuk menguji, mengukur, dan menilai tahap kecekapan tatabahasa (atau tahap penguasaan para pelajar dari aspek penggunaan kata kerja yang mendukung makna tersurat sematamata), manakala Jalaluddin dan Nopiah (2011) pula didapati telah memilih untuk memfokuskan usaha untuk menguji, mengukur, dan menilai tahap kecekapan pragmatik semata-mata (atau tahap penguasaan para pelajar dari aspek penggunaan kata kerja yang mendukung makna tersirat semata-mata) tetapi sebaliknya kajian lepas yang dilakukan oleh Abu Bakar, Jalaluddin, dan Mohamed Sultan (2019) didapati memfokuskan usaha untuk menguji, mengukur, dan menilai tahap kecekapan tatabahasa dan tahap kecekapan pragmatik secara sekali gus (atau tahap penguasaan para pelajar dari aspek penggunaan kata kerja yang mendukung makna tersurat dan makna tersirat secara sekali gus). Sebenarnya, kajian lanjutan ini merupakan kesinambungan daripada kajian lepas yang dilakukan oleh Abu Bakar et al. (2019). Hal ini dikatakan demikian kerana kajian lepas yang dilakukan oleh mereka didapati hanya melibatkan analisis kuantitatif atau inferensi semata-mata (kajian perbandingan punca dan kajian korelasi) tanpa melibatkan analisis kualitatif atau linguistik yang benar-benar mendalam yang berkaitan dengan contoh-contoh penggunaan kata kerja yang boleh melanggar sekatan pilihan.

Secara keseluruhannya, keadaan ini jelas menunjukkan bahawa perbincangan mengenai tahap penguasaan bahasa terutamanya dalam kalangan pelajar selalunya hanya dikaitkan dengan faktor-faktor persekitaran atau latar belakang seperti pengaruh faktor bahasa ibunda, faktor lokasi tempat tinggal, faktor lokasi sekolah, faktor jantina, faktor bangsa, dan sebagainya (Wong \& Yeo, 2018). Hakikatnya, jarang sekali kita dapat melihat perbincangan tentang perkaitan antara tahap penguasaan bahasa dengan bahan-bahan rujukan yang digunakan seperti yang pernah juga dinyatakan oleh Mahmood dan Yunus (seperti yang dipetik dalam Wong \& Yeo, 2018). Sehubungan dengan itu, kajian ini dilakukan bukan semata-mata bertujuan untuk mengkaji perihal tahap penguasaan bahasa dalam kalangan pelajar, bahkan pada masa yang sama, kajian ini juga sebenarnya turut memfokuskan usaha untuk mengkaji perihal kandungan yang 
berkaitan dengan huraian tentang aspek golongan kata kerja seperti yang terkandung dalam buku "tatabahasa pegangan", iaitu Tatabahasa Dewan. Hal ini dikatakan demikian kerana dalam proses pengajaran dan pembelajaran bahasa, penilaian terhadap bahanbahan rujukan utama yang akan digunakan merupakan prasyarat yang utama sebelum penilaian terhadap faktor-faktor pemerolehan bahasa yang lain seperti faktor guru, faktor murid atau pelajar, dan faktor persekitaran diambil kira (Sejo, 2012). Keutamaan yang perlu diberikan kepada usaha penilaian terhadap bahan-bahan rujukan yang sudah pun diketahui kewibawaan masing-masing sememangnya penting dalam konteks pengajaran dan pembelajaran bahasa (Sejo, 2012; Wong \& Yeo, 2018). Keadaan sebegini boleh diibaratkan seperti peribahasa "Bagaimana acuan, begitulah kuihnya" yang secara tersiratnya dapat memanifestasikan perhubungan yang erat antara pembentuk dengan hasilnya. Tambah mereka berdua lagi, dalam konteks pengajaran dan pembelajaran bahasa, "pembentuk" ini bukan hanya dapat diasosiasikan dengan guru-guru terutamanya guru-guru Bahasa Melayu itu sendiri, bahkan bahan-bahan rujukan utama untuk mata pelajaran Bahasa Melayu itu sendiri juga didapati turut mampu mempengaruhi pembelajaran bahasa seseorang murid atau pelajar.

Sehubungan dengan itu, oleh sebab pengkaji sedar akan kepentingan peranan Tatabahasa Dewan sebagai buku "tatabahasa pegangan", maka pengkaji merasakan bahawa sememangnya terdapat satu keperluan untuk melakukan kajian yang turut sama memfokuskan analisis kandungan terhadap Tatabahasa Dewan itu sendiri. Hal ini bagi melihat atau memastikan sejauh mana atau sejelas mana penghuraian aspek golongan kata kerja oleh Tatabahasa Dewan mampu menepati kehendak pengajaran dan pembelajaran tatabahasa bahasa Melayu terutamanya apabila melibatkan contohcontoh penggunaan kata kerja yang boleh juga mendukung makna tersirat. Alhasil, pengkaji mengharapkan supaya para pengguna bahasa Melayu khususnya murid-murid sekolah rendah dan juga para pelajar sekolah menengah akan mula menerima pendedahan dengan cara yang lebih berkesan tentang penggunaan bahasa mengikut konteks yang bukan hanya melibatkan maklumat linguistik, bahkan juga turut melibatkan maklumat bukan linguistik. Pada masa yang sama, guru-guru Bahasa Melayu juga diharapkan berupaya untuk mendedahkan dan mengajarkan contoh-contoh penggunaan kosa kata baharu berserta maknanya dalam berbagai-bagai konteks (Zainon Hamzah, 2010).

\section{Metodologi Kajian}

Kajian ini yang tergolong sebagai kajian kualitatif mengguna pakai kaedah analisis dokumen. Analisis kandungan yang dilakukan adalah terhadap buku "tatabahasa pegangan", iaitu Tatabahasa Dewan Edisi Ketiga. Sementara itu, tinjauan yang dilakukan melalui borang soal selidik terhadap 96 orang pelajar tingkatan enam pula bertujuan untuk melihat keberkesanan Tatabahasa Dewan dalam menghuraikan aspek golongan kata kerja memandangkannya hanya mengutamakan contoh-contoh penggunaan kata kerja yang mendukung makna tersurat semata-mata atau yang mematuhi sekatan pilihan sejak tiga dekad yang lalu. Dalam erti kata yang lebih mudah, kajian ini dilakukan 
bagi mengungkai persoalan, iaitu adakah penghuraian aspek golongan kata kerja yang hanya memberikan tumpuan kepada contoh-contoh penggunaan kata kerja yang mendukung makna tersurat semata-mata atau yang mematuhi sekatan pilihan seperti yang termaktub dalam Tatabahasa Dewan sememangnya sudah memadai dalam membantu para pelajar tingkatan enam untuk menghasilkan konstruksi ayat dengan menggunakan 25 kata kerja yang terbukti boleh juga mendukung makna tersirat?

Daripada kesemua 25 kata kerja tersebut, 15 daripadanya ialah kata kerja tak transitif, manakala selebihnya pula ialah kata kerja transitif. Apa yang pasti, 15 kata kerja tak transitif yang didapati boleh juga mendukung makna tersirat terdiri daripada "berkhutbah", "bergetah", "bercinta", "bercambah", "berkubang", "berhingus", "berkarat", "berbisik", "berlakon", "berkerak", "berbisa”, "bersinar", "berduri-duri", "bermuka-muka", dan "bertatih-tatih". Sementara itu, 10 kata kerja transitif yang didapati boleh juga mendukung makna tersirat pula terdiri daripada "menjeruk", "menabur", "membasuh", "meragut", "mengambil", "mencedok", "memotong", "menongkat", "mencurahkan" dan "membawa".

Teori Relevans dipilih berbanding teori-teori pragmatik yang lain disebabkan oleh kelebihan-kelebihan yang terdapat pada Teori Relevans itu sendiri. Antara kelebihannya ialah penginterpretasian makna yang sememangnya sentiasa menitikberatkan kewujudan konteks telah terbukti dapat membantu menyelesaikan fenomena atau masalah ketaksaan dan kekaburan makna (Jalaluddin, 1995). Lebih-lebih lagi, konteks itu sendiri kelazimannya dapat disesuaikan dengan berbagai-bagai interpretasi makna yang ingin disampaikan. Sementara itu, usaha untuk memahami sesuatu ujaran itu pula merupakan satu proses inferens yang mempunyai lingkungan makna yang luas (Subet, 2018). Selanjutnya, penerapan bidang semantik dan pragmatik dalam kajian tatabahasa sememangnya tidak dapat disangkal lagi kepentingannya. Hal ini dikatakan demikian kerana banyak kajian yang telah dilakukan membuktikan bahawa pelbagai persoalan tatabahasa dapat ditangani dan diatasi dari sudut semantik dan pragmatik khususnya melalui pengaplikasian Teori Relevans. Perkembangan pesat kajian tatabahasa yang dilakukan di Barat menerusi pengaplikasian Teori Relevans khususnya selepas tahun 1986 jelas menunjukkan bahawa Teori Relevans dapat menangani sebarang bentuk persoalan yang timbul dari sudut tatabahasa khususnya apabila melibatkan masalah ketaksaan dan kekaburan ayat yang melibatkan aspek-aspek tatabahasa yang lain seperti kata nama, kata nafi, kata bantu, dan kata hubung (Hassan, 2011).

Oleh sebab Tatabahasa Dewan telah menetapkan bahawa kata kerja dapat diklasifikasikan kepada dua jenis yang utama, iaitu kata kerja tak transitif dan kata kerja transitif, maka hanya dua kata kerja juga yang akan dianalisis dan dibincangkan daripada 25 kata kerja yang telah dikenal pasti boleh juga mendukung makna tersirat dengan masing-masing mewakili setiap satu jenis kata kerja. Kedua-dua kata kerja yang dimaksudkan ialah kata kerja tak transitif "bergetah" dan kata kerja transitif "mencurahkan". Apa yang pasti, kewajaran pemilihan hanya dua kata kerja yang akan dianalisis dan dibincangkan telah ditetapkan berdasarkan kriteria bahawa penggunaan kedua-dua kata kerja tersebut yang boleh juga mendukung makna tersirat sebagai 
antara contoh bahasa berkias Melayu yang paling mudah untuk digunakan dalam konstruksi ayat bahasa Melayu. Oleh itu, pengkaji mengandaikan bahawa kesemua tingkatan enam dapat menghasilkan konstruksi ayat dengan menggunakan kedua-dua kata kerja tersebut yang dapat menunjukkan maksud tersirat dengan betul. Ironinya, hasil daripada penilaian yang telah dilakukan jelas menunjukkan bahawa peratusan pelajar tingkatan enam yang gagal menghasilkan konstruksi ayat dengan menggunakan kedua-dua kata kerja tersebut yang dapat menunjukkan maksud tersirat masih juga mencatatkan peratusan yang agak tinggi.

\section{Dapatan Kajian dan Perbincangan}

Secara keseluruhannya, hasil penilaian tahap kecekapan pragmatik para pelajar tingkatan enam dari aspek penggunaan 25 kata kerja yang dapat menunjukkan maksud tersirat boleh dilihat menerusi Jadual 1 seperti yang dipaparkan di bawah ini.

\section{Jadual 1}

Penilaian Tahap Kecekapan Pragmatik Para Pelajar Tingkatan Enam

\begin{tabular}{|c|c|c|}
\hline \multirow{3}{*}{$\begin{array}{l}\text { No. Soalan } \\
\text { 1. berkhutbah } \\
\text { (Contoh jawapan, iaitu Emak sedang berkhutbah di dapur.) }\end{array}$} & \multicolumn{2}{|c|}{ Penilaian } \\
\hline & Betul & Salah \\
\hline & $14.6 \%$ & $85.4 \%$ \\
\hline 2. bergetah & Betul & Salah \\
\hline $\begin{array}{l}\text { (Contoh jawapan, iaitu Janda anak enam itu masih bergetah } \\
\text { seperti anak dara.) }\end{array}$ & $29.2 \%$ & $70.8 \%$ \\
\hline 3. bercinta & Betul & Salah \\
\hline $\begin{array}{l}\text { (Contoh jawapan, iaitu Kami sentiasa bercinta untuk pergi ke } \\
\text { bank pada setiap awal bulan.) }\end{array}$ & $2.1 \%$ & $97.9 \%$ \\
\hline $\begin{array}{l}\text { 4. bercambah } \\
\text { (Contoh jawapan, iaitu Syarikat kerjasama semakin bercambah_ }\end{array}$ & Betul & Salah \\
\hline di Malaysia ini.) & $3.1 \%$ & $96.9 \%$ \\
\hline 5. berkubang & Betul & Salah \\
\hline (Contoh jawapan, iaitu Dada Firaun tempat iblis berkubang.) & - & $100 \%$ \\
\hline 6. berhingus & Betul & Salah \\
\hline $\begin{array}{l}\text { (Contoh jawapan, iaitu Mahadi masih berhingus untuk } \\
\text { menyandang jawatan tertinggi dalam syarikat konglomerat itu.) }\end{array}$ & $16.7 \%$ & $83.3 \%$ \\
\hline 7. berkarat & Betul & Salah \\
\hline $\begin{array}{l}\text { (Contoh jawapan, iaitu Para pemimpin negara yang sudah pun } \\
\text { berkarat.) }\end{array}$ & $4.2 \%$ & $95.8 \%$ \\
\hline 8. berbisik & Betul & Salah \\
\hline
\end{tabular}


(Contoh jawapan, iaitu Kedengaran angin malam berbisik $\quad$ - $100 \%$ melalui jendela kamar.)

\begin{tabular}{|c|c|c|}
\hline \multirow{2}{*}{$\begin{array}{l}\text { 9. berlakon } \\
\text { (Contoh jawapan, iaitu Aminah pandai berlakon di depan ibu } \\
\text { mentuanya.) }\end{array}$} & Betul & Salah \\
\hline & $35.4 \%$ & $64.6 \%$ \\
\hline \multirow{2}{*}{$\begin{array}{l}\text { 10. berkerak } \\
\text { (Contoh jawapan, iaitu Kolar kemeja Jamal berkerak.) }\end{array}$} & Betul & Salah \\
\hline & $10.4 \%$ & $89.6 \%$ \\
\hline \multirow{2}{*}{$\begin{array}{l}\text { 11. berbisa } \\
\text { (Contoh jawapan, iaitu Mulut Qamariah memang berbisa.) }\end{array}$} & Betul & Salah \\
\hline & $36.5 \%$ & $63.5 \%$ \\
\hline \multirow{2}{*}{$\begin{array}{l}\text { 12. bersinar } \\
\text { (Contoh jawapan, iaitu Nama Aina Abdul semakin bersinar } \\
\text { dalam bidang seni suara di Malaysia.) }\end{array}$} & Betul & Salah \\
\hline & $1.0 \%$ & $99.0 \%$ \\
\hline \multirow{2}{*}{$\begin{array}{l}\text { 13. berduri-duri } \\
\text { (Contoh jawapan, iaitu Kisah perjalanan hidup rakyat Palestin } \\
\text { berduri-duri.) }\end{array}$} & Betul & Salah \\
\hline & $5.2 \%$ & $94.8 \%$ \\
\hline \multirow{2}{*}{$\begin{array}{l}\text { 14. bermuka-muka } \\
\text { (Contoh jawapan, iaitu Amirah pandai bermuka-muka di depan } \\
\text { rakan-rakannya.) }\end{array}$} & Betul & Salah \\
\hline & $27.1 \%$ & $72.9 \%$ \\
\hline \multirow{2}{*}{$\begin{array}{l}\text { 15. bertatih-tatih } \\
\text { (Contoh jawapan, iaitu Hanafi masih bertatih-tatih dalam bidang } \\
\text { keusahawanan.) }\end{array}$} & Betul & Salah \\
\hline & $18.8 \%$ & $81.3 \%$ \\
\hline \multirow{2}{*}{$\begin{array}{l}\text { 16. menjeruk } \\
\text { (Contoh jawapan, iaitu Zaleha masih menjeruk rasa dengan } \\
\text { sindiran ibu mentuanya.) }\end{array}$} & Betul & Salah \\
\hline & $9.4 \%$ & $90.6 \%$ \\
\hline \multirow{2}{*}{$\begin{array}{l}\text { 17. menabur } \\
\text { (Contoh jawapan, iaitu Zaki cuba menabur fitnah terhadap rakan } \\
\text { sekerjanya sendiri.) }\end{array}$} & Betul & Salah \\
\hline & $41.7 \%$ & $58.3 \%$ \\
\hline \multirow{2}{*}{$\begin{array}{l}\text { 18. membasuh } \\
\text { (Contoh jawapan, iaitu Mariam ingin membasuh dosa demi } \\
\text { keampunan Tuhan.) }\end{array}$} & Betul & Salah \\
\hline & $4.2 \%$ & $95.8 \%$ \\
\hline \multirow{2}{*}{$\begin{array}{l}\text { 19. meragut } \\
\text { (Contoh jawapan, iaitu Kemalangan itu telah meragut dua } \\
\text { nyawa.) }\end{array}$} & Betul & Salah \\
\hline & $17.7 \%$ & $82.3 \%$ \\
\hline \multirow{2}{*}{$\begin{array}{l}\text { 20. mengambil } \\
\text { (Contoh jawapan, iaitu Faisal ingin mengambil angin di tepi } \\
\text { pantai pada petang nanti.) }\end{array}$} & Betul & Salah \\
\hline & $21.9 \%$ & $78.1 \%$ \\
\hline \multirow{2}{*}{$\begin{array}{l}\text { 21. mencedok } \\
\text { (Contoh jawapan, iaitu Kandungan program televisyen } \\
\text { berkenaan mencedok bulat-bulat kandungan program televisyen } \\
\text { di negara Barat.) }\end{array}$} & Betul & Salah \\
\hline & $4.2 \%$ & $95.8 \%$ \\
\hline 22. memotong & Betul & Salah \\
\hline $\begin{array}{l}\text { (Contoh jawapan, iaitu Amin sering memotong kata-kata Yaakob } \\
\text { sepanjang perbualan mereka.) }\end{array}$ & $9.4 \%$ & $90.6 \%$ \\
\hline
\end{tabular}




\begin{tabular}{lcc}
\hline $\begin{array}{l}\text { 23. menongkat } \\
\text { (Contoh jawapan, iaitu Kita semua tidak akan menongkat langit.) }\end{array}$ & Betul & Salah \\
\cline { 2 - 3 } & & $97.9 \%$ \\
\hline $\begin{array}{l}\text { 24. mencurahkan } \\
\text { (Contoh jawapan, iaitu Setiap ibu bapa akan terus mencurahkan } \\
\text { kasih sayang kepada anak-anak mereka.) }\end{array}$ & Betul & Salah \\
\hline $\begin{array}{l}\text { 25. membawa } \\
\text { (Contoh jawapan, iaitu Joyah suka membawa mulut ke sana ke } \\
\text { sini.) }\end{array}$ & Betul & Salah \\
\hline
\end{tabular}

Apa yang pasti, hasil daripada penilaian yang telah dilakukan jelas menunjukkan bahawa seramai $70.8 \%$ atau 68 orang pelajar didapati gagal menghasilkan konstruksi ayat dengan menggunakan kata kerja tak transitif "bergetah" yang dapat menunjukkan maksud tersirat. Sementara itu, seramai $57.3 \%$ atau 55 orang pelajar pula didapati gagal menghasilkan konstruksi ayat dengan menggunakan kata kerja transitif "mencurahkan" yang dapat menunjukkan maksud tersirat. Keadaan ini ternyata jelas menunjukkan bahawa kesan daripada aspek golongan kata kerja yang sejak sekian lama hanya dihuraikan secara semantik semata-mata sedikit sebanyak telah merendahkan tahap kecekapan pragmatik para pelajar tingkatan enam. Oleh sebab itulah, menerusi bahagian yang berikut ini, pengkaji mengambil inisiatif untuk membantu para penulis Tatabahasa Dewan dalam memperbaik kelemahan yang masih terdapat pada penghuraian aspek golongan kata kerja dengan mengaplikasikan Teori Relevans.

\section{Kata Kerja Tak Transitif "Bergetah"}

Perhatikan dan teliti perbezaan yang terkandung dalam kelima-lima contoh konstruksi ayat di bawah ini yang dihasilkan dengan menggunakan kata kerja tak transitif bergetah.

4) Pokok itu bergetah.

5) Badan Ali bergetah kerana berpeluh.

6) Beberapa orang penduduk kampung pergi bergetah di hutan.

7) Janda anak enam itu masih bergetah seperti anak dara.

8) \#Kucing betina itu masih bergetah.

Pada dasarnya, didapati bahawa kata kerja tak transitif "bergetah" yang digunakan dalam contoh konstruksi ayat (4), (5), dan (6) ternyata masih mematuhi rumus-rumus tatabahasa bahasa Melayu seperti yang telah ditetapkan oleh Tatabahasa Dewan atau dalam erti kata yang lain masih mematuhi sekatan pilihan mengikut acuan teori tatabahasa yang berasaskan konsep Transformasi-Generatif. Sebaliknya, contoh konstruksi ayat (7) dan (8) sama sekali telah melanggar rumus-rumus tatabahasa Melayu seperti yang telah ditetapkan oleh Tatabahasa Dewan atau dalam erti kata yang lain telah melanggar sekatan pilihan. Walau bagaimanapun, kata kerja tak transitif "bergetah" yang digunakan dalam contoh konstruksi ayat (7) didapati masih dapat diinterpretasikan makna yang selanjutnya tetapi sebaliknya tidak sama sekali bagi kata kerja tak transitif "bergetah" yang digunakan dalam contoh konstruksi ayat (8). 
Hakikatnya, walaupun contoh konstruksi ayat (7) dan (8) masing-masing didapati telah melanggar sekatan pilihan, namun hanya contoh konstruksi ayat (8) yang boleh ditandai dengan simbol tanda pagar atau hashtag (\#). Sehubungan dengan itu, Teori Relevans dalam bidang pragmatik dilihat dapat membantu pengkaji dalam usaha untuk mengungkai proses kognitif yang terlibat sepanjang laluan pendengar atau pembaca dalam mencari makna sebenar yang didukung oleh kata kerja tak transitif "bergetah" dalam contoh konstruksi ayat (7). Di samping itu, konsep ad hoc peluasan juga turut boleh dimanfaatkan dalam membantu proses pemahaman berlaku. Kedua-dua proses kognitif ini diyakini dapat membantu menyelesaikan masalah ketaksaan dan kekaburan makna dan seterusnya mencungkil makna sebenar yang melibatkan contoh konstruksi ayat (7).

Proses pengekodan merupakan proses pertama yang terlibat dalam usaha untuk menginterpretasikan makna kata kerja tak transitif "bergetah" yang digunakan dalam contoh konstruksi ayat (7). Ujaran eksplisit itu dianggap sebagai rujukan kasar bagi pendengar atau pembaca untuk memahami hajat penutur. Dalam contoh konstruksi ayat (7), pendengar atau pembaca akan mengenkod konsep BERGETAH sebagai fokus untuk memahami makna sebenar "bergetah". BERGETAH dalam entri ensiklopedia akan membekalkan maklumat tentang gambaran umum, bentuk fizikal atau ciri-ciri bergetah kepada pendengar atau pembaca. Pengekodan peringkat kata untuk kata kerja tak transitif "bergetah" ini tidak memberikan maklumat yang mencukupi kepada pendengar atau pembaca, lantas pendengar atau pembaca berkemungkinan terpaksa mengenkod konsep [BERGETAH] yang diterjemahkan ke dalam bentuk logiknya sebagai mempunyai (mengandungi) getah. Penginterpretasian makna tidak terhenti setakat itu sahaja kerana pendengar atau pembaca mengetahui bahawa rujukan kamus menerusi Kamus Pelajar Edisi Kedua (2015) telah menjelaskan bahawa BERGETAH merupakan kiasan yang menggambarkan sifat-sifat yang ada pada wanita, iaitu menarik dan menggiurkan (berkenaan bentuk badan, cara berpakaian, dan sebagainya, tentang wanita). Dari perspektif Teori Relevans, pendengar atau pembaca akan memanfaatkan prosedur pemahaman Teori Relevans bagi memastikan bahawa usaha memproses maklumat adalah rendah tetapi pendengar atau pembaca masih perlu mendapatkan kesan kognitif yang tinggi dengan memilih interpretasi yang dapat memuaskan jangkaan relevan yang dapat dijangkakan sebagai hasrat sebenar penutur. Oleh itu, pendengar atau pembaca perlu mengaplikasikan konsep ad hoc peluasan apabila pendengar atau pembaca perlu meneruskan proses pemahaman yang disebabkan oleh contoh konstruksi ayat (7) merupakan ujaran yang mengandungi implikatur. Kandungan eksplisit digabungkan dengan konteks bagi mendapatkan implikatur. Konsep [BERGETAH] diluaskan kepada [BERGETAH*]. Dalam [BERGETAH*], konsep menarik dan menggiurkan ditambah. Dalam hal ini, andaian-andaian akan terus diakses dan masih menjadi rujukan utama untuk membentuk andaian-andaian implikatur yang relevan dengan ujaran yang berkenaan. Selanjutnya, pendengar atau pembaca haruslah merujuk konteks ayat bagi memastikan ketepatan andaian-andaian implikatur yang dibina. Konteks ujaran merujuk kepada penilaian yang dibuat terhadap seorang janda yang didapati walaupun sudah pun mempunyai seramai enam orang anak tetapi dirinya tetap atau sentiasa kelihatan lebih 
muda daripada umurnya yang sebenar. Rentetan daripada proses ini, beberapa andaian implikatur dapat dibina yang seterusnya dapat dijadikan sebagai rujukan untuk mencari makna sebenar "bergetah" seperti yang berikut:

1) Janda anak enam itu masih bergetah seperti anak dara.

2) Wanita yang sudah pun berumur tetapi masih kelihatan menarik dan menggiurkan.

3) Wanita yang sudah pun berumur tetapi tidak kelihatan tua.

4) Wanita yang sudah pun berumur tetapi masih kelihatan muda.*

Dalam usaha untuk memahami kata kerja tak transitif "bergetah" yang digunakan dalam contoh konstruksi ayat (7), andaian-andaian yang terdapat dalam konsep yang dienkod banyak membantu membentuk konsep ad hoc yang baharu. Kelazimannya, [BERGETAH*] hanya akan memfokuskan ciri-ciri luaran atau fizikal wanita. Oleh itu, Jadual 2 di bawah ini merupakan rumusan daripada analisis kata kerja tak transitif "bergetah" yang mendukung makna tersirat.

\section{Jadual 2}

Rumusan Analisis Kata Kerja Tak Transitif Bergetah yang Mendukung Makna Tersirat

\begin{tabular}{|c|c|c|c|c|c|}
\hline Kata Kerja & Bentuk Logik & $\begin{array}{c}\text { Andaian } \\
\text { Implikatur }\end{array}$ & $\begin{array}{l}\text { Kesimpulan } \\
\text { Implikatur }\end{array}$ & $\begin{array}{l}\text { Makna } \\
\text { Sebenar }\end{array}$ & $\begin{array}{l}\text { Konsep } \\
\text { Ad Hoc }\end{array}$ \\
\hline $\begin{array}{l}\text { kata kerja } \\
\text { tak transitif } \\
\text { bergetah }\end{array}$ & $\begin{array}{l}\text { mempunyai } \\
\text { (mengandungi) } \\
\text { getah }\end{array}$ & $\begin{array}{l}\text { 1. Wanita yang } \\
\text { sudah pun } \\
\text { berumur } \\
\text { tetapi tidak } \\
\text { kelihatan tua. } \\
2 . \text { Wanita yang } \\
\text { sudah pun } \\
\text { berumur } \\
\text { tetapi masih } \\
\text { kelihatan } \\
\text { muda. }\end{array}$ & awet muda & $\begin{array}{l}\text { memuji atau } \\
\text { menyindir }\end{array}$ & peluasan \\
\hline
\end{tabular}

Secara ringkasnya, maksud "bergetah" seperti yang terkandung dalam contoh konstruksi ayat (7) mengikut Teori Relevans akan sentiasa mengambil kira konteks penggunaannya dan juga konteks budaya. Hal ini bermakna dalam konteks bahasa harian, sesuatu perkataan yang lazim digunakan tidak selalunya akan membawa maksud asalnya tetapi sebaliknya boleh membawa maksud yang lain bergantung pada penggunaannya. Oleh sebab itulah, pragmatik leksikal telah dikenal pasti sebagai suatu subtopik pragmatik yang semakin berkembang saban hari. Hal ini dapat dilihat menerusi pertambahan bukti perubahan maksud sesuatu perkataan yang boleh berlaku secara automatik dan ada kalanya, sesuatu perkataan itu jarang membawa maksud asalnya (Subet, 2018). Hal ini jelas menunjukkan bahawa kepentingan strategi pemahaman makna perkataan berasaskan konteks penggunaan ternyata dapat membantu muridmurid sekolah rendah dan juga para pelajar sekolah menengah untuk memahami makna 
sesuatu perkataan yang diajarkan terutamanya bagi mana-mana perkataan yang boleh mendukung makna dua lapis. Sebenarnya, pengkaji mendapati bahawa kata kerja tak transitif "bergetah" yang digunakan dalam contoh konstruksi ayat (7) boleh juga dikategorikan sebagai kiasan melarat. Kiasan melarat merujuk kepada kiasan daripada perkataan yang sudah pun menyimpang jauh daripada maksud asal perkataan tersebut (Goay \& Choo, 2003). Pada masa yang sama, kata kerja tak transitif bergetah yang boleh juga dikategorikan sebagai kiasan melarat seterusnya boleh juga diklasifikasikan sebagai grammatical idioms berpandukan huraian yang pernah dikemukakan oleh Fillmore, Kay, dan O'Connor (1988). Hal ini ternyata jelas membuktikan bahawa makna untuk sesuatu rangsangan bahasa bukan hanya boleh dianalisis secara semantik, bahkan pada masa yang sama, makna untuk sesuatu rangsangan bahasa itu boleh juga dianalisis secara pragmatik (Hamid, 2006). Walau bagaimanapun, jurang antara rumus terjemahan semantik linguistik dengan rumus tafsiran semantik yang kosong hanya dapat diisi oleh pragmatik dan konteks (Hassan, 2011).

Apa yang lebih menariknya tentang contoh konstruksi ayat (7) ialah konstruksinya tetap mematuhi rumus-rumus tatabahasa bahasa Melayu seperti yang telah ditetapkan oleh Tatabahasa Dewan. Dalam erti kata yang lebih mudah, contoh konstruksi ayat yang mengandungi kata kerja bergetah yang mendukung makna tersirat didapati tetap mematuhi sekatan gramatis atau grammatical restrictions. Pada dasarnya, konsep sekatan gramatis ini pernah dibahaskan oleh Palmer (1976). Oleh hal yang demikian, Jadual 3 dan Jadual 4 seperti yang dipaparkan di bawah ini dapat menunjukkan bahawa contoh konstruksi ayat (7) sememangnya tetap mematuhi sekatan gramatis memandangkannya boleh memenuhi setiap peringkat hierarki tatabahasa sama seperti contoh konstruksi ayat (4).

\section{Jadual 3}

Contoh Analisis Penggunaan Kata Kerja Tak Transitif Bergetah yang Mendukung Makna Tersurat Berdasarkan Hierarki Tatabahasa

\begin{tabular}{|l|c|l|l|}
\hline AYAT & \multicolumn{3}{|l|}{ Pokok itu bergetah. } \\
\hline KLAUSA & pokok itu bergetah & \multicolumn{2}{l|}{ bergetah } \\
\hline FRASA & pokok itu & bergetah \\
\hline PERKATAAN & pokok & itu & \\
\hline
\end{tabular}

\section{Jadual 4}

Contoh Analisis Penggunaan Kata Kerja Tak Transitif Bergetah yang Mendukung Makna Tersirat Berdasarkan Hierarki Tatabahasa

\begin{tabular}{|l|l|l|l|l|l|l|l|l|l|}
\hline AYAT & \multicolumn{4}{|l|}{ Janda anak enam itu masih bergetah seperti anak dara. } \\
\hline KLAUSA & \multicolumn{4}{|l|}{ janda anak enam itu masih bergetah seperti anak dara } \\
\hline FRASA & \multicolumn{3}{|l|}{ janda anak enam itu } & \multicolumn{2}{|c|}{ masih bergetah } & \multicolumn{3}{|c|}{ seperti anak dara } \\
\hline PERKATAAN & janda & anak & enam & itu & masih & $\begin{array}{c}\text { ber- } \\
\text { getah }\end{array}$ & seperti & anak & dara \\
\hline
\end{tabular}




\section{Kata Kerja Transitif Mencurahkan}

Perhatikan dan teliti perbezaan yang terkandung dalam ketiga-tiga contoh konstruksi ayat di bawah ini yang dihasilkan dengan menggunakan kata kerja transitif "mencurahkan".

1. Ayah mencurahkan air ke longkang.

2. Setiap ibu bapa akan terus mencurahkan kasih sayang kepada anak-anak mereka.

3. \#Saya ingin mencurahkan diri ke dalam bidang perniagaan.

Pada dasarnya, didapati bahawa kata kerja transitif mencurahkan yang digunakan dalam contoh konstruksi ayat (9) ternyata masih mematuhi rumus-rumus tatabahasa bahasa Melayu seperti yang telah ditetapkan oleh Tatabahasa Dewan atau dalam erti kata yang lain masih mematuhi sekatan pilihan. Sebaliknya, contoh konstruksi ayat (10) dan (11) sama sekali telah melanggar rumus-rumus tatabahasa bahasa Melayu seperti yang telah ditetapkan oleh Tatabahasa Dewan atau dalam erti kata yang lain telah melanggar sekatan pilihan. Walau bagaimanapun, kata kerja transitif "mencurahkan" yang terkandung dalam contoh konstruksi ayat (10) didapati masih dapat diinterpretasikan makna yang selanjutnya tetapi sebaliknya tidak sama sekali bagi kata kerja transitif "mencurahkan" yang terkandung dalam contoh konstruksi ayat (11). Walaupun kata kerja transitif "mencurahkan" yang digunakan dalam contoh konstruksi ayat (10) boleh mengalami pelanggaran sekatan pilihan sememangnya sudah terbukti boleh juga tergolong sebagai kiasan melarat, namun apa yang menarik perhatian ialah konstruksi ayat tersebut sama sekali tidak menunjukkan unsur ketaksaan atau ambiguity. Dalam erti kata yang lebih mudah, penggunaan kata kerja transitif "mencurahkan" dalam contoh konstruksi ayat (10) telah menunjukkan penggunaan yang biasa atau lazim sehinggakan tidak kelihatan lagi cirinya sebagai kiasan melarat. Bornstein (1977) menyatakan bahawa kadangkala penggunaan sesetengah metafora tidak lagi dianggap sebagai pelik memandangkannya telah diterima sebagai kebiasaan dalam berbahasa seperti kata kerja "fly" yang digunakan dalam The bird flew out of its nest dan The woman flew out of the room in a rage. Hakikatnya, keadaan inilah yang telah menyebabkan pengkaji terlalu yakin bahawa kesemua pelajar tingkatan enam dapat menghasilkan konstruksi ayat dengan menggunakan kata kerja transitif "mencurahkan" yang dapat menunjukkan maksud tersirat dengan betul.

Ironinya, walaupun kata kerja transitif "mencurahkan" yang digunakan sebagai kiasan melarat dalam contoh konstruksi ayat (10) boleh dianggap sebagai antara contoh bahasa berkias yang paling mudah untuk dicerna maknanya memandangkannya didapati lebih mudah untuk difahami oleh kanak-kanak dan lebih cepat diproses oleh orang dewasa (Baba, 2015) tetapi sebaliknya, hanya seramai $42.7 \%$ atau 41 orang pelajar tingkatan enam yang dapat menghasilkan konstruksi ayat dengan menggunakan kata kerja transitif "mencurahkan" yang dapat menunjukkan maksud tersirat dengan betul. Keadaan ini ternyata jelas membuktikan bahawa selama lebih tiga dekad 
penerbitannya, Tatabahasa Dewan didapati hanya mengutamakan atau memfokuskan penghuraian contoh-contoh penggunaan kata kerja transitif yang mematuhi sekatan pilihan. Di samping itu, keadaan ini juga ternyata jelas membuktikan bahawa huraian tentang aspek golongan kata kerja seperti yang telah dikemukakan oleh Tatabahasa Dewan masih belum mapan atau mantap sepenuhnya. Secara eksplisit, kata kerja transitif "mencurahkan" yang digunakan sebagai kiasan melarat dalam contoh konstruksi ayat (10) sememangnya amat mudah untuk diberi maknanya oleh semua penutur bahasa Melayu. Hal ini dikatakan demikian kerana dari sudut kognitif, penggunaan kata kerja transitif "mencurahkan" sebagai kiasan melarat dapat menjimatkan proses mental kerana satu adegan yang berkaitan dengan satu peristiwa dalam minda kita dapat digambarkan dengan hanya merujuk satu peristiwa atau fakta yang lain secara tidak langsung (Ho Abdullah, 2011; Baba, 2015). Walau bagaimanapun, oleh sebab kegagalan seramai $57.3 \%$ atau 55 orang pelajar tingkatan enam menghasilkan konstruksi ayat dengan menggunakan kata kerja transitif "mencurahkan" yang dapat menunjukkan maksud tersirat, maka pengkaji merasakan bahawa analisis dan perbincangan tentang proses mencari makna sebenar kiasan melarat ini tetap perlu juga ditunjukkan memandangkannya juga adalah antara bahagian penting daripada bahasa berkias Melayu (Baba, 2015).

Pendengar atau pembaca akan mengenkod konsep [MENCURAHKAN KASIH SAYANG] sebagai proses pertama pemahamannya. Rumus logik yang terhasil daripada pemahaman peringkat semantik ini berkemungkinan menjelaskan bahawa [MENCURAHKAN KASIH SAYANG] merujuk kepada mencucurkan, menuang (menyimburkan, melimpahkan, menumpahkan) dengan banyaknya. Dari perspektif Teori Relevans, prosedur pemahaman Teori Relevans akan dimanfaatkan oleh pendengar atau pembaca bagi memastikan bahawa rendahnya usaha memproses maklumat tetapi sebaliknya tinggi dari segi kesan kognitifnya yang sememangnya masih perlu diperoleh dengan memilih interpretasi yang dapat memuaskan jangkaan relevan yang dapat dijangkakan sebagai hasrat sebenar penutur. Oleh sebab contoh konstruksi ayat (10) merupakan ujaran yang mempunyai makna implisit, maka pendengar atau pembaca akan mengaplikasikan konsep ad hoc peluasan apabila pendengar atau pembaca perlu meneruskan proses pemahaman. Kandungan eksplisit digabungkan dengan konteks bagi mendapatkan implikatur. Konsep [MENCURAHKAN KASIH SAYANG] diluaskan kepada [MENCURAHKAN KASIH SAYANG*]. Dalam [MENCURAHKAN KASIH SAYANG*], konsep memberi banyak-banyak ditambah. Dalam hal ini, andaian-andaian terus diakses dan masih menjadi rujukan utama untuk membentuk andaian-andaian implikatur yang relevan dengan ujaran yang berkenaan. Seterusnya, pendengar atau pembaca perlu merujuk konteks ayat bagi memastikan ketepatan andaian-andaian implikatur yang dibina. Konteks ujaran merujuk kepada usaha setiap ibu bapa yang sentiasa sedaya upaya mencuba untuk memberikan kasih sayang yang sebanyakbanyaknya kepada anak-anak mereka. Sehubungan dengan itu, beberapa andaian implikatur pun dapat dibina yang seterusnya dapat dijadikan sebagai rujukan dalam usaha untuk mencari makna sebenar "mencurahkan kasih sayang" seperti yang berikut: 
1) Setiap ibu bapa akan sentiasa mencurahkan kasih sayang kepada anak anak mereka.

2) Setiap ibu bapa berperanan memberikan kasih sayang yang secukupnya kepada anak-anak.

3) Kasih sayang ibu bapa terhadap anak-anak tidak boleh berkurangan walau sedikit pun sampai bila-bila.

4) Kasih sayang ibu bapa terhadap anak-anak sememangnya tidak bertepi.*

Apa yang pasti, dalam usaha untuk memperoleh maksud sebenar "mencurahkan kasih sayang", pendengar atau pembaca dibantu oleh kesemua andaian kontekstual dan pengetahuan latar belakang (background knowledge). Oleh itu, Jadual 5 di bawah ini merupakan rumusan daripada analisis kata kerja transitif mencurahkan yang mendukung makna tersirat.

\section{Jadual 5}

Rumusan Analisis Kata Kerja Transitif Mencurahkan (Kasih Sayang) yang Mendukung Makna Tersirat

\begin{tabular}{|c|c|c|c|c|c|}
\hline Kata Kerja & Bentuk Logik & $\begin{array}{l}\text { Andaian } \\
\text { Implikatur }\end{array}$ & $\begin{array}{l}\text { Kesimpulan } \\
\text { Implikatur }\end{array}$ & $\begin{array}{l}\text { Makna } \\
\text { Sebenar }\end{array}$ & $\begin{array}{l}\text { Konsep } \\
\text { Ad Hoc }\end{array}$ \\
\hline $\begin{array}{l}\text { kata kerja } \\
\text { transitif } \\
\text { men- } \\
\text { curahkan }\end{array}$ & $\begin{array}{l}\text { mengeluarkan } \\
\text { banyak-banyak }\end{array}$ & $\begin{array}{l}\text { 1. Setiap ibu } \\
\text { bapa } \\
\text { berperanan } \\
\text { memberikan } \\
\text { kasih sayang } \\
\text { yang } \\
\text { secukupnya } \\
\text { kepada anak- } \\
\text { anak. } \\
2 . \text { Kasih } \\
\text { sayang ibu } \\
\text { bapa terhadap } \\
\text { anak-anak } \\
\text { tidak boleh } \\
\text { berkurangan } \\
\text { walau sedikit } \\
\text { pun sampai } \\
\text { bila-bila. }\end{array}$ & $\begin{array}{l}\text { Kasih sayang } \\
\text { ibu bapa } \\
\text { terhadap } \\
\text { anak-anak } \\
\text { sememang- } \\
\text { nya tidak } \\
\text { bertepi. }\end{array}$ & ikrar & peluasan \\
\hline
\end{tabular}

Seterusnya, apa yang menariknya tentang kata kerja transitif "mencurahkan" yang digunakan dalam contoh konstruksi ayat (10) yang boleh mengalami pelanggaran sekatan pilihan ini ialah kehadirannya tetap mematuhi rumus-rumus tatabahasa bahasa Melayu. Dalam erti kata yang lebih mudah, konstruksi ayat tersebut didapati tetap mematuhi sekatan gramatis. Di samping itu, pengkaji juga turut mendapati bahawa kata kerja transitif "mencurahkan" yang digunakan dalam contoh konstruksi ayat (10) yang 
boleh mengalami pelanggaran sekatan pilihan sama sekali tidak mengalami sekatan sintaktik atau syntactic restrictions seperti yang pernah dibahaskan oleh F. R. Palmer (1976). Hal ini bermakna contoh konstruksi ayat (10) boleh dipasifkan sama seperti contoh konstruksi ayat yang mematuhi sekatan pilihan, iaitu konstruksi ayat (9). Buktinya adalah seperti yang berikut:

9) Kasih sayang akan terus dicurahkan oleh setiap ibu bapa kepada anak-anak mereka.

10) Kasih sayang akan terus dicurahkan $\varnothing$ setiap ibu bapa kepada anak-anak mereka.

11) Kasih sayang akan terus dicurahkan kepada anak-anak mereka oleh setiap ibu bapa.

12) *Kasih sayang akan terus dicurahkan kepada anak-anak mereka $\varnothing$ setiap ibu bapa.

\section{Kesimpulan}

Sebagai rumusan, hasil daripada analisis yang telah dilakukan jelas membuktikan bahawa pendekatan semantik dan pragmatik melalui pengaplikasian Teori Relevans merupakan satu pendekatan yang dapat digunakan untuk menganalisis dan memahami contoh-contoh penggunaan kata kerja yang boleh juga mendukung makna tersirat atau yang boleh juga melanggar sekatan pilihan. Hal ini bermakna ilmu semantik sememangnya mesti digandingkan dengan ilmu pragmatik memandangkan pada peringkat semantik, pemberian makna yang lengkap masih belum dapat dicapai. Hal ini juga turut disokong oleh Lyons dan beliau berpendapat bahawa ahli-ahli semantik harus menerima kenyataan atau hakikat yang sebenar bahawa terdapat makna yang dikodkan oleh sesuatu leksikal atau struktur tatabahasa dalam sesuatu konstruksi ayat yang gagal ditangani oleh mereka (Hassan, 2011). Tambah Hassan (2011) lagi, berdasarkan kenyataan yang dikemukakan oleh Lyons, ternyata jelaslah bahawa ilmu semantik sememangnya memerlukan bantuan ilmu pragmatik bagi menghasilkan analisis makna yang lebih mendalam dan sempurna. Hal ini dikatakan demikian kerana sudah pun jelas terbukti bahawa semantik tidak dapat menangani elemen-elemen bukan linguistik yang merupakan maklumat tambahan bagi menginterpretasikan makna yang dapat ditangani oleh ilmu pragmatik. Dari sudut Teori Relevans, semantik dan pragmatik ternyata berbeza dan perbezaan ini adalah dari segi proses kognitif yang berlaku dalam proses penginterpretasian sesuatu ujaran, iaitu pengekodan dan inferens. Oleh sebab itulah, keadaan ini sememangnya menuntut usaha penilaian dilakukan terhadap buku "tatabahasa pegangan", iaitu Tatabahasa Dewan itu sendiri seperti yang pernah disarankan oleh Jalaluddin, Ahmad, dan Aman (2004), Abdullah (2007), dan Ahmad (2013).

Apa yang pasti, tokok tambah dalam Tatabahasa Dewan diyakini akan dapat mengukuhkan lagi kredibiliti dan kewibawaannya sebagai buku "tatabahasa pegangan". pula, buku ini sememangnya sangat berguna kepada para pengguna bahasa Melayu 
khususnya murid-murid sekolah rendah dan juga para pelajar sekolah menengah memandangkan buku ini dapat mendekatkan lagi diri mereka dengan "dunia" bahasa Melayu di samping matlamat utama untuk mempertingkatkan kemahiran berbahasa dalam mata pelajaran Bahasa Melayu (Mohd. Rasidi, 2000). Sehubungan dengan itu, pengkaji berpendapat bahawa penghuraian aspek golongan kata kerja yang dikemukakan oleh Tatabahasa Dewan sememangnya perlu ditambah baik dengan turut sama memasukkan input-input baharu yang telah diperoleh oleh kajian ini. Oleh itu, para penulis Tatabahasa Dewan semestinya mengambil inisiatif dalam melakukan kerjakerja pembetulan atau penambahan selari dengan penemuan input-input baharu dalam bidang tatabahasa (Mohd. Rasidi, 2000). Kini, sudah tiba masanya juga untuk komponen pragmatik turut diajarkan dan didedahkan secara formal menerusi Tatabahasa Dewan sama seperti komponen morfologi, komponen sintaksis, dan komponen semantik. Hal ini dikatakan demikian kerana sudah pun jelas terbukti bahawa konteks ujaran yang melibatkan elemen-elemen bukan linguistik tidak mampu dijelaskan oleh teori-teori tatabahasa yang andal termasuklah Teori Transformasi-Generatif itu sendiri tetapi sebaliknya dapat ditangani dengan sebaik-baiknya oleh teori pragmatik yang satu ini, iaitu Teori Relevans (Abu Bakar et al., 2019).

\section{Rujukan}

Abu Bakar, K. T., Jalaluddin, N. H, \& Mohamed Sultan, F. M. (2019). Golongan kata kerja: Korelasi antara kecekapan tatabahasa dengan kecekapan pragmatik dalam kalangan remaja Malaysia. Jurnal Linguistik, 23(1), 70-101.

Ahmad, Z. (2013). Nahu praktis bahasa Melayu: Menangani kepelbagaian, mencari keserasian. Penerbit Universiti Kebangsaan Malaysia.

Baba, H. (2015). Bahasa berkias dan nilai Melayu: Analisis pragmatik [Unpublished Doctoral Thesis, Universiti Kebangsaan Malaysia, Bangi, Malaysia].

Bornstein, D. D. (1977). An introduction to transformational grammar. University Press of America.

Dawi, N. F. (2010). Penguasaan kata kerja dalam kalangan pelajar bacelor sastera Universiti Putra Malaysia [Unpublished Masters Thesis, Universiti Putra Malaysia, Serdang, Malaysia].

Fillmore, J. C., Kay, P., \& O' Connor, M. C. (1988). Regularity and idiomaticity in grammatical constructions: The case of let alone. Language, 64(3), 501-538.

Goay, T.C., \& Choo, S. T. (2003). Teks pra-u: Bahasa Melayu kertas 1. Pearson Malaysia Sdn. Bhd.

Hamid, Z. (2006). Aplikasi psikolinguistik dalam pengajaran dan pembelajaran bahasa: Siri pengajaran dan pembelajaran bahasa Melayu. PTS Professional Publishing Sdn. Bhd.

Hassan, H. (2011). Kata hubung dan dan tetapi dari sudut pragmatik. Dewan Bahasa dan Pustaka. 
Ho Abdullah, I. (2011). Analisis kognitif semantik peribahasa Melayu bersumberkan anjing (canis familiaris). GEMA Online ${ }^{T M}$ Journal Language Studies, 11(1), 125141.

Jalaluddin, N. H. \& Nopiah, J. (2011). Penguasaan tatabahasa remaja Malaysia: Analisis pragmatik. Jurnal Bahasa, 11(1), 63-82.

Jalaluddin, N. H. (1992). Ganti nama Melayu Sarawak: Analisis teori linguistik. Akademika, 40(1), 19-38.

Jalaluddin, N. H. (1992). Semantik dan pragmatik: Satu pengenalan. Dewan Bahasa dan Pustaka, Kementerian Pendidikan Malaysia.

Jalaluddin, N. H. (1995). Fungsi dan pola ganti nama Melayu: Satu interpretasi semantik dan pragmatik. AKADEMIKA, 47, 85-99.

Jalaluddin, N. H. (2007). Bahasa dalam perniagaan: Satu analisis semantik dan pragmatik. Dewan Bahasa dan Pustaka.

Jalaluddin, N. H., Ahmad, Z., \& Aman, I. (2004). Penguasaan bahasa Melayu oleh pelajar Melayu dalam arus globalisasi. Jurnal Bahasa, 4(1), 63-95.

Kamus Pelajar Edisi Kedua. (2015). Kuala Lumpur: Dewan Bahasa dan Pustaka.

Karim, N. S, Onn, F. M, Musa, H., \& Mahmood, A. H. (2009). Tatabahasa dewan edisi ketiga. Dewan Bahasa dan Pustaka.

Mohd. Rasidi, R. (2000). Penilaian penulisan buku tatabahasa bahasa Melayu: Satu analisis 'teori' atqakum [Unpublished Masters Thesis), Universiti Malaya, Kuala Lumpur, Malaysia].

Omego, C., Anyanwu, O., \& Onyegbuchulam, A. (2012). Verb-noun (object) selectional restriction in Ebughu. Theory and Practice in Language Studies, 2(11), 2226-2238. https://doi.org/10.4304/tpls.2.11.2226-2238

Oweleke, E. (2019). Aspects of the semantics and pragmatics of verb-noun selection restrictions in Igbuzo-lgbo. AFREV, 13(2), 120-130. http://dx.doi.org/10.4314/afrrev.v13i2.10

Palmer, F. R. (1976). Semantics: A new outline. Cambridge: Cambridge University Press.

Sejo, M. Z. (2012). Penekanan ilmu morfologi dalam buku teks bahasa Arab KBSM. Persidangan Kebangsaan Pengajaran dan Pembelajaran Bahasa Arab 2012, Bangi, Malaysia.

Singer, R. (2016). The dynamics of nominal classification: Productive and lexicalised uses of gender agreement in Mawng. Jerman: Walter de Gruyter Inc.

Sperber, D., \& Wilson, D. (1995). Relevance: Communication and cognition. Oxford: Basil Blackwell.

Subet, M. F. (2018). Analisis teori relevans dalam metafora. Jurnal Bahasa, 18(1), 159188.

Wagner, A., \& Mastropietro, M. (2017, April 9). Collecting and employing selectional restrictions. Technical report. https://www.semanticscholar.org/paper/Collectingand-Employing-Selectional-Restrictions-Wagner-

Mastropietro/635a2d1878fc4f5aa57cf6bbc10aae7bd4a0ddeb\#references

Wong, S. H. \& Yeo, S. K. (2018). Percanggahan pendapat aspek tatabahasa: Perbandingan antara bahan rujukan bahasa Melayu. PENDETA Journal of Malay 
$\begin{array}{llll}\text { Language, Education } \quad \text { and } & \text { Literature, }\end{array}$ https://doi.org/10.37134/pendeta.vol9.2.2018

Zainon Hamzah, Z, A. (2010). Pemantapan pengajaran dan pembelajaran bahasa Melayu di sekolah menengah. Jurnal Linguistik, 10, 63-82. 